\title{
Intrerchange of Heat in Saw Disc Body During Cutting
}

\author{
J. SVOREŇํ, L' . JAVOREK², L'. NAŠČÁK ${ }^{3}$ \\ Institute: Faculty of environmental and manufacturing technology, Technical University in Zvolen, \\ E-mail: jan.svoren@tuzvo.sk ${ }^{1}$; lubomir.javorek@tuzvo.sk²; lubomir.nascak@tuzvo.sk ${ }^{3}$
}

Abstract. The paper presents the experimental results of a research aimed at the distribution of the temperature on the circular saw blade body. The temperature was measured at two distances from the centre of the circular saw blade body $(70 \mathrm{~mm}, 140 \mathrm{~mm})$ by means of an infrared thermometer. Two circular saw blades with the diameter of $350 \mathrm{~mm}$ and a variable adjustment of the body (with slots and without the coating, with both slots and coating) were used for the longitudinal sawing of the spruce wood (Picea excelsa) with the thickness of $h=37 \mathrm{~mm}$. Feed speeds ware vf $1=14 \mathrm{mpm}, v f 2=17 \mathrm{mpm}$ and $v f 3=20 \mathrm{mpm}$. Cutting revolutions $n=4100 / \mathrm{min}$. were constant. The measured temperature was in the range from $21^{\circ} \mathrm{C}$ till $27^{\circ} \mathrm{C}$. The highest measured temperatures were recorded on the circular saw blade with the slots and coating.

Keywords: circular saw blade, infrared thermometer, temperature, wood cutting

\section{INTRODUCTION}

One of the most important factors showing the impact on the working ability of the circular saws is the heating of the circular saw blade. Therefore, the research of thermal phenomena and the assessment of the heating factor are of great importance for the innovation and efficient use of circular saws for wood cutting. Existing scientific approaches to temperature and woodworking have a dominant effect on friction temperature but the issues of intensity characteristics and temperature sensors are not sufficiently described. The sawing process by the circular saws is the most used process in woodworking, where circular saw blades are the cutting tools. The basic problems of tool instability in the cutting process are vibration and noise of the circular saw blade (8) and (17). The most significant obstruction during cutting by the circular saw blade is the aberration (deformation) of the circular saw blade in a plane (7). The effect is only caused by compressive stress in the circular saw blade which is dependent on the temperature distribution status inside. Knowing the accurate temperature distribution is one of the main points to solve the problem. The measurement of the circular saw blade temperature during a high cutting speed ( $\left.\mathrm{v}_{\mathrm{c}}=50 \mathrm{mps} \div 100 \mathrm{mps}\right)$ is not easy. Some results have been brought by the experimental works of the authors. (1), (4), (6) and (14) used at the experimental measuring the method of thermocouple (copper - konstantan) with the diameter wire $d=(0.125 \div$ $0.15) \mathrm{mm}$. The measuring of the temperature on the circular saw blade body with the infrared thermometer and with infrared camera is published by authors (2), (3), (4), (9), (10), (11), (12), (13), (15), (17). 


\section{MATERIAL AND METHODS}

Researching the temperature distribution on the circular saw blade in the cutting process, two circular saw blades were used at the experimental measurements. The first examined circular saw blade was with compensation and radial slots (CSB1), the second one was with compensation and radial slots and with the spray paint RAL 9006 (CSB2). Used circular saw blades are shown in Fig. 1a (CSB1) and in Fig. 1b (CSB2).

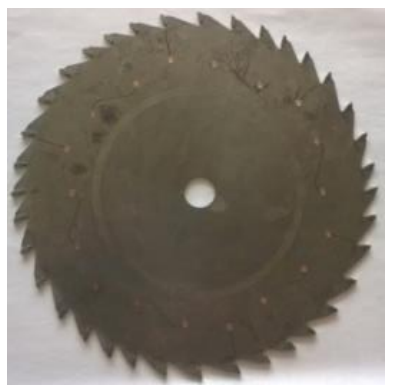

a)

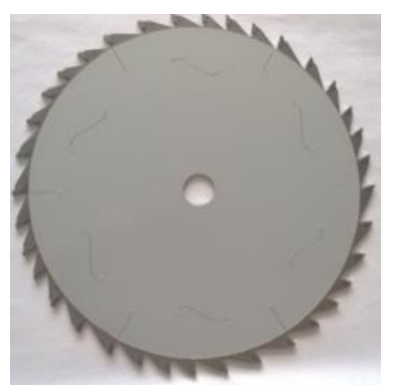

b)

Figure 1. The circular saw blades used for the experimental measurements

The basic parameters of the circular saw blades used in the experiment are given in Tab. 1.

Table 1 The basic parameters of used circular saw blades

\begin{tabular}{|l|c|c|}
\hline \multicolumn{1}{|c|}{ Parameters } & CSB1 & CSB2 \\
\hline Saw blade diameter (mm) & 350 & 350 \\
\hline Clamping hole diameter (mm) & 30 & 30 \\
\hline Number of teeth (-) & 36 & 2.4 \\
\hline Body thickness (mm) & 2.4 & 4 \\
\hline Length of the cutting edge (mm) & 4 & 13 \\
\hline Tooth height (mm) & 13 & $\alpha_{\mathrm{f}}=15^{\circ}$ \\
\hline Pitch of teeth (mm) & \multicolumn{2}{|c|}{$\beta_{\mathrm{f}}=65^{\circ}$} \\
\hline \multirow{2}{*}{ Tooth geometry } & $\gamma_{\mathrm{f}}=10^{\circ}$ \\
\cline { 2 - 3 } & \multicolumn{2}{|c|}{} \\
\cline { 2 - 3 } &
\end{tabular}

The sawing process was performed on a circular saw with a continuous feed through a belt conveyor and top clamp by a roller feeder. A block diagram of the experimental apparatus for measuring the temperatures of the circular saw blade during the cutting is shown in Fig. 2. The cutting plates from spruce (Picea excelsa) with dimensions: thickness $h=37 \mathrm{~mm}$, width $b=400 \mathrm{~mm}$, length $\mathrm{L}=1500 \mathrm{~mm}$, $\mathrm{w}=$ a humidity of $12 \%$ were used. Overhang of the circular saw blade was $60 \mathrm{~mm}$ over the belt conveyor. The slats of $20 \mathrm{~mm}$ width were gradually cut off from the boards. The cutting conditions of the performed cutting are shown in Tab. 2 . 


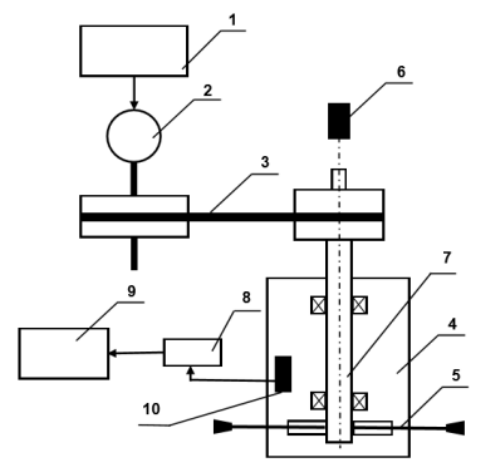

Figure 2. The block diagram of the connecting instruments for measurement of the temperature in cutting process on the circular saw blade

1 - frequency converter Siemens A.6. MM550/3, 2 - electric motor Siemens P = $5.5 \mathrm{~kW}, 3$ - belt drive, 4 -circular saw frame, 5 - circular saw blade mounted with clamping collars dp $=110 \mathrm{~mm}, 6-$ noncontact speedometer 2236, 7 - shaft stored in the bearings, 8 - digitálny multimeter MXD-4660 A, 9 - PC, 10 -Infrared Thermometer OmegaScope 0S520.

Table 2. The cutting conditions

\begin{tabular}{|c|c|c|c|c|c|}
\hline & $\begin{array}{c}\text { Feed speed } \\
v_{\mathrm{f}}\left(\mathrm{m} \cdot \mathrm{min}^{-1}\right)\end{array}$ & $\begin{array}{c}\text { Rotation } \\
n\left(\mathrm{~min}^{-1}\right)\end{array}$ & $\begin{array}{c}\text { Cutting } \\
\text { high } \\
\mathrm{h}(\mathrm{mm})\end{array}$ & $\begin{array}{c}\text { Cutting } \\
\text { length } \\
\mathrm{L}(\mathrm{mm})\end{array}$ & $\begin{array}{c}\text { Temperature } \\
\text { of surround } \\
\text { air } \mathrm{T}_{0}\left({ }^{\circ} \mathrm{C}\right)\end{array}$ \\
\hline CSB1, CSB2 & $14 ; 17 ; 20$ & 4100 & 37 & $1500 ; 3000 ; 4500$ & 17 \\
\hline
\end{tabular}

The experimental measurement of the circular saw blades temperature on the circular saw in a cutting process was carried out at the measuring apparatus whose block diagram is shown above. The measurement was performed at two distances from the centre of the circular saw blade. The sensor axis was adjusted at the distances of $70 \mathrm{~mm}$ and $140 \mathrm{~mm}$ from the centre of the circular saw blade. The sensor was located $150 \mathrm{~mm}$ from the side surface of the circular saw blade.

\section{RESULTS AND ANALYSIS}

As a result, the numbers in a txt format files were obtained which were further processed. Statistical analysis was conducted using software STATISTICA12. All measured data met the requirements and were tested using analysis of variance (ANOVA). The mean values of measured temperatures were compared using post-hoc test at 5\% significance level to determine the differences among the select predictors.

\section{The dependence of temperature on the type of a circular saw blade (at the distance of $70 \mathrm{~mm}$} and $140 \mathrm{~mm}$ )

Analysis of variance showed significant influence of using type of a circular saw blade on the temperature measured at the distance of $70 \mathrm{~mm}$ and $140 \mathrm{~mm}$ from the shaft axis. In both cases, comparing CSB1 to CSB2, the temperature by using CSB1 was significantly lower. 
Specifying the significant differences between individual types of circular saw blades, the post-hoc test was done and validated the result that the mean values of temperature measured on CSB1 and CSB2 are noticeably different. The result is valid for both measured distances from shaft axis.

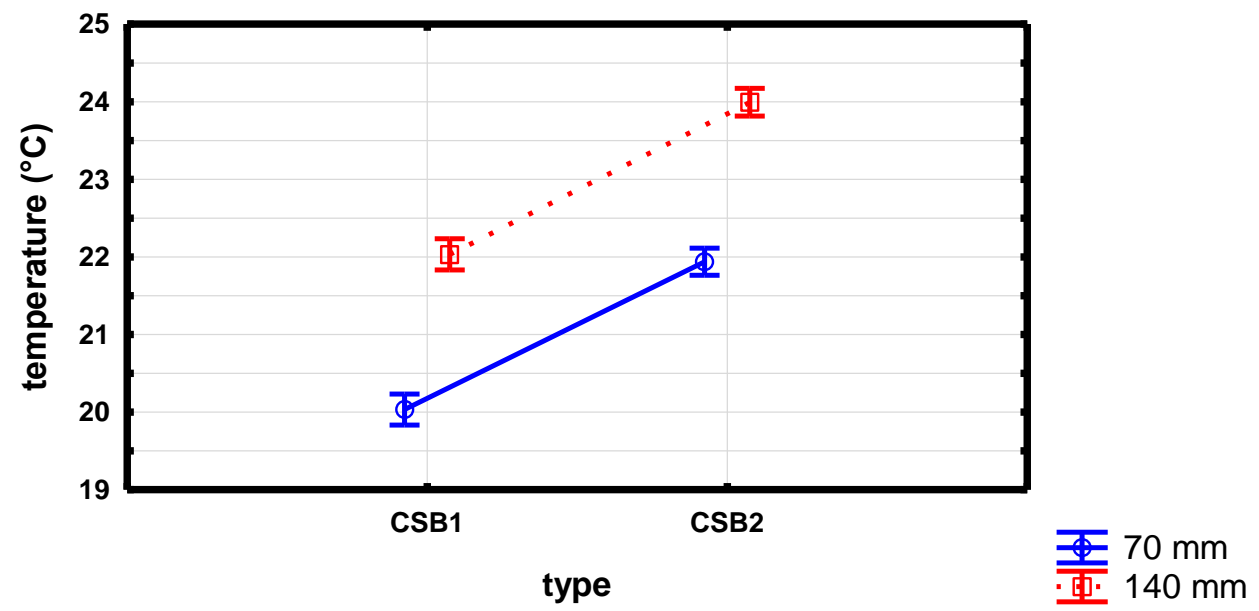

Figure 3. Plot of mean temperature for the effect of a circular saw blade type

The graph in Fig. 3 indicates the clear increasing tendency in the both cases. It can be seen that using CSB2 resulted in increased temperature significantly.

Fig. 4 shows temperatures measured of the circular saw blade (CSB2) during the wood cutting process. After a rapid increase in the circular saw blade body temperature ( 1 to 3 seconds), we see a slight change in temperature, up to the end of the cutting, up to $1 \stackrel{\circ}{\circ}$.

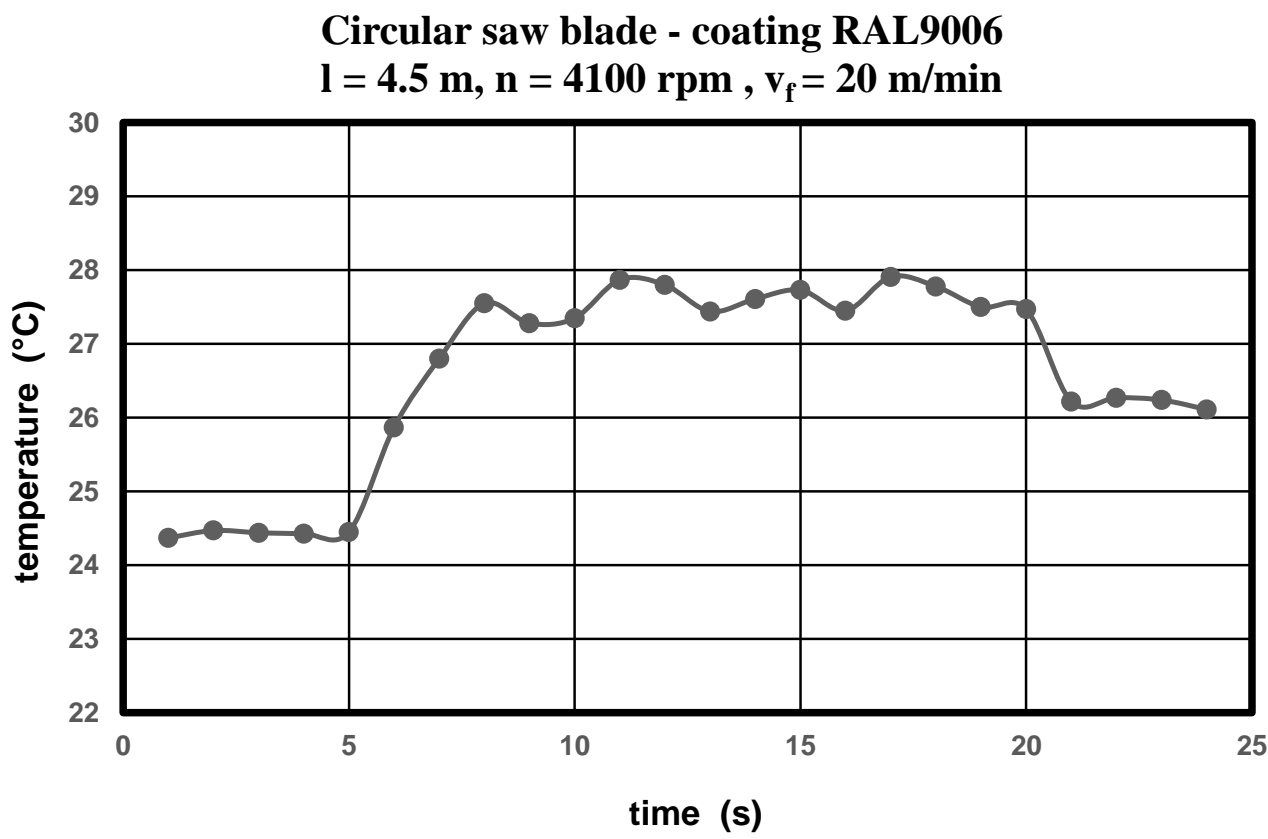

Figure 4. Temperature measured of the circular saw blade (CSB2)

Based on the experimental measuring (6) shows that the temperature at the distance of $0.5 \mathrm{~mm}$ from the cutting edge reaches the maximum value $T=500{ }^{\circ} \mathrm{C}$, in the sector of the tooth root $T=(52 \div 110)$ 
${ }^{\circ} \mathrm{C}$ and at the region of the clamping collars $T=(22 \div 46){ }^{\circ} \mathrm{C}$. The temperatures depend on the cutting conditions. The cutting conditions in the experimental measuring were: $v_{\mathrm{c}}=(37.9 \div 66.7) \mathrm{m} / \mathrm{s} ; f_{\mathrm{z}}=(0.2$ $\div 1) \mathrm{mm} ; h=(70 \div 150) \mathrm{mm}$ and $w=(10 \div 70) \%$. (1), in their work, indicate the temperature in the area under the root circle at four different radiuses. Cutting material was used with dimensions: Thickness $h=(75$ and 100$) \mathrm{mm}$, width $b=250 \mathrm{~mm}$, length $l=(2.5$ and 3.1$) \mathrm{m}$. The highest temperature measured in the cutting was near of the tooth root and reached $T=26.7^{\circ} \mathrm{C}$. (14) report the results of experimental temperature measurements on the tooth, with 6 thermocouples were sequentially located $1 \mathrm{~mm}$ from the cutting edge. The highest measured temperature is $1 \mathrm{~mm}$ from the cutting edge: for particleboard $T=196{ }^{\circ} \mathrm{C}$, for the solid wood $T=127^{\circ} \mathrm{C}$. The temperature $T=669^{\circ} \mathrm{C}$ was determined in the cutting process on the surface of the cutting edge (11). Authors (5) evaluated coefficient of thermal emissivity for the mentioned temperature ranged $T=(30 \div 100)^{\circ} \mathrm{C}$ varied $(0.2 \div$ 0.34 ) when measured by infrared thermometers.

Our experimental temperatures measurement of the circular saw blade body was in the range $T=(20$ $\div 27)^{\circ}$ C. The temperatures and coefficients of thermal emissivity were in very good equality with the experimental works of the quote authors. From the experimental measurements it can be concluded: CSB2 had the highest temperature for each of the two distances $(70 \mathrm{~mm}$ and $140 \mathrm{~mm}$ ) from the centre of the saw blade (Fig. 5). CSB2 had a special surface treatment, it had the spray paint RAL 9006 with a thickness of 100 microns. From the results we can deduce that the injection affected the temperature of the saw blade (in the expected heat transfer coefficient $-\alpha$ ) which cooled slowly. This finding corresponds well with the differential Eq. 2. The temperature at two different radiuses of the saw blades confirms the theoretical assumption of concentric temperature distribution with a temperature gradient from the edge to the radius of the clamping flanges of the saw blade.

Fig.4 shows a rapid rise in the circular saw blade body temperature at 1 to 3 seconds. Then the thermal equilibrium occurs in of the circular saw blade body. The part of the heat generated by the cutting process is from the edge to the centre of the circular saw blade conduct. The same part of the heat is from the surfaces of the circular saw blade to the surrounding environment radiated. As a result of this phenomenon, the temperature of the circular saw blade in the cutting process is further increased.

\section{CONCLUSIONS}

The experimental measuring confirmed the influence of circular saw blade body modification on the concentrical distribution of temperature in the radial direction of the circular saw blade:

1. From the selected technological parameters, the highest temperature gradient causes the length of the cutting wood L, and the change of the temperature gradient from the feed speed is not statistically significant.

2. The smaller temperature gradient was evident on the circular saw blade with a surface coated in a thin layer of RAL 9006 material.

3. The coating of surface of circular saw blade with using of thin layer is possible way how to change its attributes. We suggest this obtained experience to confirm and develop with following research. 


\section{REFERENCES}

[1] J. D. Danielson -G. S. Schajer (1993) Saw Blade Heating and Vibration Behavior in a Circular Gang Edger. In: Proceedings of Saw Tech '93 - 3rd. Internatoinal conference on sawing technology; 1993 October 14-16; San Francisco, CA. Berkeley, CA: Wood Machining Institut: pp. 117-136.

[2] M. Ishihara - N. Noda - Y. Ootao (2010) Analysis of dynamic characteristics of rotating circular saw subjected to thermal loading and tensioning. Journal Therm Stresses 33(5) pp. 501-517.

[3] M. Jug - R. B. Lučic -A. O. Čavlovic - B. Šafran (2017) Effect of feed speed on bluntness and warming of circular saw in sawing beech and oak wood. In: Proceedings 23rd Interntional Wood Machining Seminar, 28.05.2017- 31.05.2017-Warsaw-Poland, pp. 240-249.

[4] M. A. Khvijuzov - A. N. Galashev (2013) Raschet temperatury nagreva poverkhnosti pil'nogo diska pri osushchestvlenii pirometricheskogo kontrolya (Temperature calculation of the blade heating surface in the implementation of the control Pyrometer). Lesnoy zhurnal. 1 pp. 60-65.

[5] M. A. Khvijuzov - A. N. Galashev - I. I. Soloviev (2015) Kompensacija medodičeskoj pogrešnosti pri IK- kontrole nagreva kruglych pil (Compensation of method error in the infrared heating control of circular saws). Lesnoy zhurnal. 6 pp. 107-115.

[6] V. N. Konov (1982) Issledovanie temperaturnogo polja kruglych pil pri raspilovke drevesiny. Stankii instrument derevobrabatyvajuščich proizvodstv. Mežvuzovskij sbornik naučnych trudov. Vypusk 9, Leningrad, pp. 3-6.

[7] Z. Kopecký - M. Rouser (2012) Impact of dominant vibrations on noise level of dimension circular sawblades. Wood Research 57(1) pp. 151-160.

[8] B. Lehmann (2007) Heating and cooling of circular saws. In: J.Taylor and D.Wong (eds) Volume I - oral presentations of the 18th international wood machining seminar. Vancouver: The IWMS18 Organizing Committee. pp. 47-58.

[9] L. Li - B. T. Xi - Y. F. Yang (2002) Thermal and rotary stresses in circular saw blades. Journal of Beijing Forestry University 24(3) pp. 14-17.

[10] L. Li - B. T. Xi - Y. F. Yang (2007) Transverse deflection of circular saw and sawing profile on workpiece. Journal of Beijing Forestry University 29(1): 141-145.

[11] H. v. Martinez - M. Hankele (2015) Simulation of the circular sawing process. Copyright by Dynamore GmbH. 10th European LS-DYNA Conference 2015, Würzburg, Germany

[12] A. Mohammadpanah - B. Lehmann - J. White (2017) Development of a monitoring system for guided circular saws, experimental investigation. In: Proceedings 23rd Interntional Wood Machining Seminar, 28.05.2017- 31.05.2017-Warsaw-Poland, pp. 84-98.

[13] C. D. Mote - A. Rahimi (1983) Real time vibration control of rotating circular plates by temperature control and system identification. IFAC Adaptive Systems in Control and Signal Processing, San Francisco, USA, pp. 171-178.

[14] J. Ratnasingam -T. Pew MA - G. Ramasamy (2010) Tool temperature and cutting forces during the machining of particleboard and solid wood. Journal of Applied Sciences 10(22) pp. 2881-2886.

[15] J.Y.Sheikh-Ahmed - C.M. Lewandowski - J.S. Stewart (2003a) Experimental and numerical methods for determing temperature distribution in a wood cutting tool. Exp. Heat Transfer $16 \mathrm{pp}$. 225-271.

[16] J. Svoreň - L'. Javorek - L'. Naščák (2017) The effect of the circular saw blade body structure on the temperature along the radius during the wood cutting process. In: Proceedings 23rd Interntional Wood Machining Seminar, 28.05.2017- 31.05.2017-Warsaw-Poland, pp. 261-268. 
International Journal of Engineering and Management Sciences (IJEMS) Vol. 4. (2019). No. 1

DOI: 10.21791/IJEMS.2019.1.60.

[17] H. Sugihara - K. Sumiya (1955) A theoretical study on temperature distribution of circular sawblade. Wood Research Bull. No.15 of the Kyoto University, Kyoto, Japan, pp. 60-74. 